な拈威力を発揮するという点に関しては，大いに之を高く評価していいのでは無いかと思う．勿論 吾々が経験したのは僅かに一例であつて，すべての例において，本報告例の如き輝かしい効果を示 し得るものかどうかは将来の経験に待たねばならぬ事はいらまでも無い所である.

吾々は各種抗生物質の偉効に愕いて感服する反面に，その色々な副作用の苦々しさをも忘れては いない.特に耳鼻咽喉科領域に执いて問題となる所のものは, S.M.の使用に依つて惹起される難聴や 耳鳴である. 現在においては殆んど適切な治療法がないという此の副作用, 更に一般的にいうなら ば, 食㥕不振, 覀心, 腹痛, 下痢等の消化器系統に及ぼす影響, 最も副作用の少ないP.においても, 菌の大量が一挙に死隇することに依つて惹起される虚脱症状の出現, 即ちへルクスハテマー氏反応 が報ぜられているし，腸内細菌群に作用する結果生ずるビタミンの体内悀成不全から起る口内炎の こと, 造血機能障碍に基く負血, 白血球減少症, 顆粒球減少症等数え来れば幾多の副作用を挙げる 事が出来るのであるが，それ等には又，適宜予防法が講ぜられて来ていて，抗生物質の使用に際し ての口内炎を顧虑する時には，V.-B. の複合体を予め使用するとか，その又使用量を適当に加減す るとか，種々の土夫が発表されている．何れにしても如何に副作用があつても現今最も有効な薬物 とされて居る抗生物質に菌が耐性を獲得する事は心淋しいと観じて居た所に，第 6 番目の I.L.が出 てくれた事は吾々臨床家として心強い限りである. 反面此の薬が又効かなくなつた場合のことも, 今から考えて置く必要があるのではないか，その方法の一つとして吾々の今考劣る事は過去から現 在に到る迄引きつづき生命をもつ治療法たとえば脳膜炎の際の腰椎穿刺, 䯚景液排除への重要性の再 認識という事の示晙を以て本報告の終りとしたい.

\title{
結瞩
}

吾々は，慢性化膿性中耳炎の急性増悪症に，急性乳様突起炎を併発して患者の術後発生した耳性 化膿性脳膜炎に対し，在来の各種抗生物質の耐性獲得を感応錠に依り認めたのであるが，アイロタ イシン $144 \mathrm{gr}$ の使用に依り, 之を死地から脱せしめる事が出来た。

諸薬物服用中特に挙ぐべき副作用は之を認めない。

\section{眼窩蜂窠織咨を合併己た慢性複合性 副鼻腔炎の化学療法に因万治験例}

\author{
神 戸市 \\ 近藤 兼吉
}

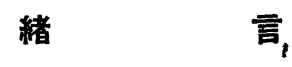

慢性副鼻腔炎の治療は簡単に見えて実は甚だ困難なもので, 従来種々の治療法が行われているが， 何れる満足な治㾍を得ず，唯病変粘膜完全除去を目的とする所謂根治手術のみが比較的好成績を挙 げ得るのでこの療法が高く評価せられ, 慢性副鼻腔炎といへば必ず根治手術を唯一の治療法の如く 一般に認識されている. 然し根治手術たるや实際名の如く根治せないものすくなくなく,術後色々の 症状が起り又再発も稀でない. 鼻腔は複雑な解剖学的情造を有し,根治手術の目的が病変粘膜の完全 除去にある以上これが徹底を期する事は比較的困難なるのみならず，䍜患頻度が最も多い上顎洞炎 


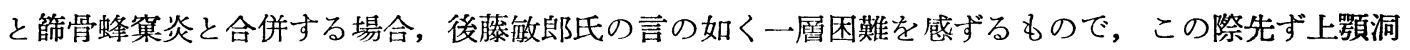
根治術をなしこれょり節骨蜂菓の病巣を㨕爬し, 末光, 伊藤両氏の説の如く一週間後に更に経鼻的 に篩骨蜂巢の病单残存粘膜を除去するを常道とするが，篲骨蜂菓病変粘膜の完除は香會我部博士の 説の如く甚だ困難で再三残存粘膜除去を反復して其徹底が期せられる〉もので，幸に理想的に除去 完遂せられても必ずしも全治するとはいえない.これDomochowsky, Manasse, Nuhsiman, 保, 天 野, 堀口諸氏の立証する如く病変は大抵隣接骨壁に波及して抒り骨壁に赤色点とか表面粗精化瞥骨 あるいは遊離骨形成の如き骨病変を認むる事実に遭遇する事多く, 従つて病変粘膜除去のみでは全 治の困難なる所以で, 幸に術後適切なる治療に依り治癒を得ても広沉なる組織侵襲に依り時に鼻腔 の形態に変化を来たし，生理的機能の低下を予期せねね゙ならない，要するに外科的治療による患者 の受くる苦痛を免れしめ, また術後障碍などの不快なる恼みをなくし, 然も手術に劣らざる療法があ れば本病治療の一進歩といわなければならない. 茲に化学的療法が期待せられるのである.

1948年 5 月の Readers` Digest 東洋版に Colombia 大学教授 Alvan L. Barach 博士の「ペニシリ ン」の煙蓩療法に因り慢性上顎洞蓄膿症に $80 \%$ の治癒率を得たる記載あると, 吾等専門医界に一大 反響を喚起し,幾多の、Expert。に依り随次この追試成績は発表せられ，その効果については甲論乙駇， いまだ結論には到達していないが，何れも非観血的療法として夢想だにしなかつた優れた療法たる 事は挙げて是認する所である，私は昭和 24 年 2 月「ペニシリン」(以後ぺと略す)の入手が容易とな ると直ちに慢性上顎洞蓄膿症の治療には同凪の洞汒療法を試み, 爾来留意精進し 既に24年11月兵庫 県医学会および25年 9 月兵庫地方会においてその経験報告を行い，「ぺ」の貯蔵と運営に万全を期 するに抢いては驚くべき成果を拳げ得る事を確認した。本症例の如き合併症を起した場合従来鼻外 的に先ず篩骨蜂巢を開き症状緩和を待ち，二次的に上顎竇根治術および篩骨蜂窠掻爬術を行うにあ つたが，鼻外法は美容上極力避け，鼻内的に然し中鼻道天蓋の一部を鉗除して笠骨蜂寨の排膿を易 からしめ全幅の希望を化学的療法に期待し快心の治癒を得たのでその大略を述べ大方の御参考の一 助となれば望外の幸いである。

症

患者：18才 古 未婚 初誩 昭和26.12.21.

主訴 : 左眼突出, 眼简痛, 碩痛, 悪寒, 舅閉寒

家族歴：特記すべきるはない

既往病歴：生来健康,3才の時麻疹の外著患はない。 15才の春月経来潮,其の他とくに記すべきるのはない，

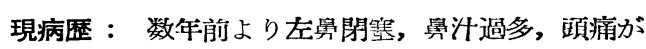
あつたが意に介せず放任した所, 3 日前風邪に崔り顕痛 が加わり時々舅根部に鈍痛を感じて居たが昨夜突然悪



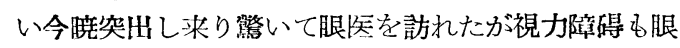
底变化むないとて本院に紹介せられて来た。

現症：休格中等, 栄僐倩良, 胸腹部異常ない。腱 反射少しく元進する外，四肢以異状はない，休温39.8 C

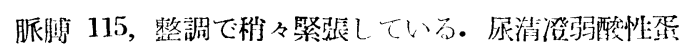
白孔糖孔認めない。

局所所見：顔貌稍々苦觉を呈し左腿球前外方に笑

\section{例}

出し左上下眼瞼腫脹し, 畧梁正中線に及び内半発赤し 疼痛の為眼球運動はできない。眼球結膜に Chemosis あり瞳孔の光線反射稍々遅鈍, 眼底に变化ない. 視力

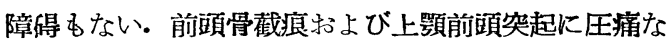
いが眼简内側ことに涙骨後方に圧痛が湛だしく腪脤に 波動を感じない。

畧腙は左中下甲介の粘膜肥厚し, 中畕道に膿汁が充 ちている.清拭すると天蓋粘膜は浮腫状に電れている。 右側下甲介軽度肥厚の外特に記すべきすのはない。後 舅鏡検查では左中舅道に腰汁附着し下甲介後端肥厚. 口腔抢よび耳に異常はない。

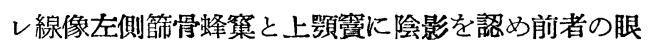

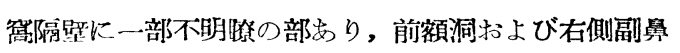
榢に除影を認めない。

診断： 以上の所見より慢性上顽洞炎之穊骨蜂笨壁 の一部状破堙せられで，炎症の眼窩内に波及したもの 
と考えられる・

㾜法：美容の上より顔面に手術切創を加える事は 眼球障㥂か脳症状の様な重篤な症状の起らない限り極 力避けたき事で，大藤教授は先ず嘼内的に節骨蜂㹎炎 を手術し上顎洞炎のみ化学的㞠佚を行つて効果を挙げ て抢られるが, 私の症例は症状が可なり劇しいので眼 召内になるべく刺践の及ばざる様にするため簛骨蜂笨 炎に対し単に中悬道天蓋を銝除して䆞内濃计の排出を 容易ならしめるに止め, Mix「へ」1cc5000 単位含有液 で除々に窠内を洗涤，さらに同剤浸潤䄸少タンポンを 行い外部に $2 \%$ 醂酸水の冷湿布その上に氷囊貼布, 同時

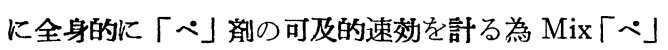
20 万単位を 3 時間毎に三分割妫注最終に同時に油製プ ロカイン「ヘ」30万を筇注した. かくて厳重に経過を 見守る事とした。翌日疼痛稍々緩和し高熱下降の兆を 示し局所の腫脹は増大せず,眼球にも異状はない.前日

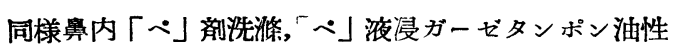
プロカイン「へ」60万的注, 自覚症状次第に谣和し来 り, 第 3 病日には局所の発赤は褪色し初め, 腫脹稍々 淢少し来り体温 $38 \mathrm{C}$ 台に下降して来たため上顎管畒 膿症の治療を始めた。下鼻道側壁を穿刺吸引するに覀 寄性混血蒙緑灰色の昖散性濃厚なる 㬝汁多量おり，隇菌蒸溜水にて洞内 洗淮膘汁の消失を待ち $\mathrm{Mix} 5$ 万単 位含有 $1 \%$ ネオゲリゾン混合液 $3 \mathrm{cc}$ 注大患側に側臥30分更に節骨笨内一 液洗浲べ液浸綿少タンポン施行, 更 に油性プ・ベ60万単位解注する.上頻 寨内膿汁には多数の葡萄状球菌, 双 球菌および少数の連鎖状球菌を検出 した・第 4 病日眼臉の腫脹疢第に娍 退し体温も下降し来る. 前日同様上 影洞内混合液洞注, 穊骨蜂笨へ・液浸 綿紗タンポン油性べ30万筇住.した。 第 5 病日眼臉腫脹著しく減じ眼球復



考
㴆し運動尋常となり, 疼痛なく, 上顎洞獧汁, 濃厚粘液 性となり洞濁は薄らぎ前日同様処置. 第6病日に膿汁は 半透明粘液性となりその量は減少して来た。前日同様 の処置. 第 7 病日患部腫脹全く去り顔貌尋常前日同様 好置. 第 8 病日体温全く尋常となり眼球全く常態に恢 復した。 上顎洞膿汁稀薄透明粘液性少量となり, 前同様 処置。第9病日自覚的症状は全く消失した。油性一脇注 中止.の外前同様妈置. 第10病日上顎洞膿什全く消失し 更に混合液洞注篩骨蜂笨内べ液漫綿紗タンポン反復施 行した. 第11病日自覚的症状全く消失し他覚的に中下 両甲介の腄脹も著しく減退し中悬道清浄となる. 爾来 Mix ぺ液 lcc（2 万単位含存）の煙霧療法の及連日 施行する事10日間, 即ち治療開始以来20日で自他覚的 症状全く消失し一時治痖を見るに到つた。本症例治療 に要したべ風総量は次の如くである.

油性プロカイン・ベニシリン管住総量 350 万単仗上 顎洞注: Mix ヘニニシリン 8 回総量 40 万単位.煙霧療法, Mix ベニシリン 10 日間総量 20 万単位. 本年 4 月来院 治療終了後何等暴常なく 1 年有余後において子症状な く, 全く治揬を確認した。 
手術を行わない為この部位を確証する事は出来なかつたが 局所所見およびレ線像より慢性に経過し た篩骨蜂菓炎が風邪により急性化し,開放性であつたものが閉塞性となり, Scheffer, Burger 両氏の

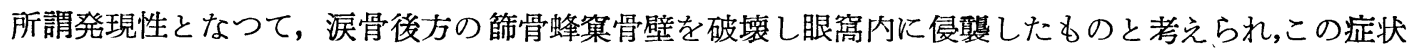
の急激なる所より蜂巢織炎と推定する.本症の起菌炎に就ては従来烧多の報告あり羽田, 和田, 三好, 小西, 近藤等の研究は各多少の差異はあるが, 何れも検出多量でつた菌としては黄色, 白色葡萄状球 菌, 溶血性連鎖状菌, 緑膿菌, インフルエンザ菌, カタル性菌, 肺炎双球菌, 類デフテッ一菌等で, この 中葡萄状扣よび連鎖状球菌の比率大きく特に葡萄状球菌はWoodward 氏によれば合併症を起す際 多く認めると強調している, 本症例は葡萄状球菌, 双球菌, および少量の連鎖状球菌を検出して扣り, W氏のいう葡菌を多量に含有し，何れもぺ斉に高い感受性を有している,本症例の如き所見を呈する 場合には,従来 Bachman 氏術式に従い舅外的に眼窩内縁に達する切開を加え眼窩内側骨膜を剝離し 節骨蜂巢を開放し症状の緩和を待ち二次的に上顎窅根治手術および節骨蜂菓搔爬を行うにあるが,化 学療法の登達した今日に打いては眼球障碍むるいは脸症状の如き重篤なる症状がない限り，極力美 容上鼻外法を避け大藤博士の説の如く先ず鼻内的に節骨蜂菒炎の手術を行い, 次いで上顎洞炎のみ 化学的療法を行うを賢明の策と考兄られる．副鼻腔炎殊に上顎洞慢性蓄膿症に対する化学的療法は

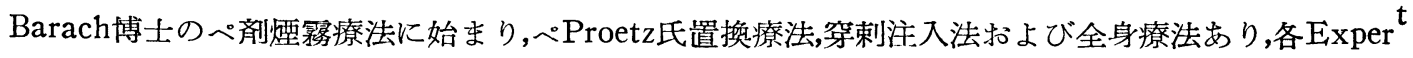
に依り治瘾率に多少の差異を示し大沢氏はぺ筋注打よび Proetz 氏法併用で全治50-60\%，佳良を加 え90\%，尾明氏は洞注のみにて全治55\%，佳良も加え同じく90\%，近藤は洞注のみにて全治55\%， 著効 $25 \%$, 佳良 $10 \%$, 計 $90 \%$, 本田氏は洞注で全治 $60 \%$, 佳良 $30 \%$, 無効 $10 \%$, 田中・德永両氏は著効 $72 \%$ の成績を発表している.一方岡野, 土肥両氏は抗生物質に上る上顎洞炎の治療は著効は認めるが 治瘾困難なる事を報告しているが,大沢氏の言の如く化学的療法は全部完全には治癒し得るとは云え ないが全体的効果は根治手術の治瘾率に劣らないのみならず 手術療法は稀に出血多量で不幸の転帰 を取り,あるい:副損傷の為の眼障碍を起し, 女るいは重篤な脳膜炎の如き合併症を併発し時に術後 性煩膿癔あるいは術後性猩紅熱等不快なる術後障碍を起す事も稀でなく,これに反し本療法はかつる 危険は更になく,年秢の如何を問わず小児老人にも容易に行われ, 治療毎に症状の軽快を自他共に認 められ前述の如き成績が拳がり, 従来夢想だにしなかつた進歩せる治療法たる事を立証している.慢 性上顎洞炎にぺ斉局所応用の治瘾的機転に関し細菌の感受性のみでは解せられず，ぺの刺戟による 病変粘膜の反応にて粘膜内に白羽, 島田の両訪の如く血管の新生, 繊維芽細胞の出現を促進し次第に 組織改善せられて治療に赴くものと解するを妥当と考兄られる．従つて長年月に亘り病変した組織 が単に一回の連続治療に依り、大抵最長10日間前後にて膿汁消失する)全治を云々するのは早計に失 する恐れあり, ある時日を隔して(私は 3,4 月)反復治療して始めて治㾍を得べく,時に第 1 回の連続 治療のみにて数カ月後に治癒を確認する事尠からず, 田村博士の如きもべ斉洞注連日施行しなお粘 液排泄するのを放任すると数カ月後治癒を見たるむのが多数あつたのを述べている．本症例も幸い 病原菌悉くぺに感受性高いもののみで前述の如く 1回の連続治療で 臨床上治癒を見, 更に 1年余の経

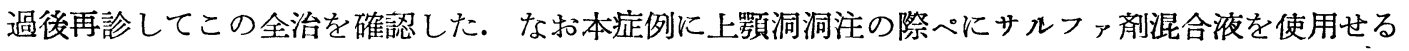
時サ剤がペと協力作用を営みぺ薬効を強化すると云う説に従うもので, 慢性上顎洞炎の化学的療 法に対し「アレルギー」あるいは洞粘膜嘎毛上皮の脱落或は機能不全の者には期待薄の説があるが ぺの薬理を涊識し，この貯蔵と運営に細心の注意を払い3〜4カ月の間隔を以て反復治療を行うに括 いては，必ずしも全部治療するとは考えないが必ずや予期以上の治癒を見る事を固く信ずるもので, 本症例の如き合併症を起した場合に沶いてすら，前述の如き治癒を得たのを見ても明かな所である， 


\section{結語}

18才未婚の女子慢性節骨蜂菓炎と上顎洞蓄膿症の複合性副鼻腔炎が感嘪により急性化し，笠骨蜂


二次的に上顎洞根治手術および穊骨蜂巢搔爬術を行うのを, 美容上極力悬外法を避け, 鼻内的に然 も中鼻道天蓋の 1 部を鉗除して之の排膿を計りしのみにてすべて非観血的にペニシリン 捛よびサル ファ剤の化学的療法に依り快心の治癒を得た。

本症例は日本纍咽喉科学会15回関西地方会にてその要旨を講演した

交

献

1) Onodi u. Mygind. : Hb. d. H-N-O Heilk Bd.

15) 吉野：" 55; 5 , II (A. Denker, O. Kahler.)

2) 香既我部：日本耳鼻咽喉科全書第 5 巻 2

16) 中村 (正) : 56; 7,

3）白羽：日医新報 1325 , 昭 24

4) 三方：” 1328, 昭 24

5) 大藤：” 1342, 昭 25

6) 西端：”-1352, 昭 25

7) 後藤：” 1450, 昭 27

8）小倉：日耳鼻 $53 ； 1$,

9）権藤：" " 9 ,

10) 大沢 : " $54 ; 1,2,3,4,5$,

11) 近櫒: " $54 ; 9$

17）吉川：耳鼻臨床 $43 ; 5$,

18）高橋・権田：" 44;8,

19) 末光, 伊滕：” 45; 4 ,

20）大島：” 45; 9 ,

21) 估保：耳喉科 $22 ; 10$,

22) 川岡: " $22 ; 11$,

23) 大藤：” $22 ; 12$,

24) 高橋: ” $23 ; 3$,

25) 仁保・稻揲：》 $23 ; 10$,

12) 中村: " $54 ; 12$,

26) 川村 : ” 24; 12 ,

13）高橋 - 石川：” 55; 3 ,

27) 今井:" 25;

14) 飯野:" $55 ; 3$,

28）渡辺：" $25 ; 3$,

\section{上顎 癌 知 見 補 遺 \\ 京都大学医学部耳悬咽喉科学教室（主任 後藤光治 教授）}

浅 井良三藤 岡 俊 彥

上顎癌の治療成績はあまりょくない，我が教室の広戸の統計によると19\%の治療率である，此の 治療した症例を観ると腫瘍が上顎洞内に限局せる早期のもの, 歯牙より発生せるもの, 頸腺転移な きもの等で,すべて早期診断せられたもののみである. 即ち上顎癌の治療成績を向上せしめるには早， 期診断が最も重要であつて他藏器のそれと全く趣を同じくするのである.

上顎癌の早期診断には症状, レ線検查, 試験穿剌, Papanicoleau 検查, 等種々なる事項が挙げ られるが，我々は上顎癌患者の病杯が如何にあるか，ことに副鼻腔炎との関係について調查した。 蓋し長与又郎博士の調查によると我国には上薠癌が多いが之は副鼻腔炎が多いことによるといわ れ，上顎癌と副舅腔炎との間に一定関係を認めている. 勿論上顎癌のほとんどすべては蓄膿症を伴う のであるが然し蓄膿症が上顎癌発生を促すとは直ちにいい難いからである。 